IZA DP No. 5148

Can Educational Expansion Improve Income Inequality in China? Evidences from the CHNS 1997 and 2006 Data

Guangjie Ning

August 2010 


\title{
Can Educational Expansion Improve Income Inequality in China? Evidences from the CHNS 1997 and 2006 Data
}

\author{
Guangjie Ning \\ Nankai University \\ and IZA
}

\section{Discussion Paper No. 5148 \\ August 2010}

\author{
IZA \\ P.O. Box 7240 \\ 53072 Bonn \\ Germany \\ Phone: +49-228-3894-0 \\ Fax: +49-228-3894-180 \\ E-mail: iza@iza.org
}

Any opinions expressed here are those of the author(s) and not those of IZA. Research published in this series may include views on policy, but the institute itself takes no institutional policy positions.

The Institute for the Study of Labor (IZA) in Bonn is a local and virtual international research center and a place of communication between science, politics and business. IZA is an independent nonprofit organization supported by Deutsche Post Foundation. The center is associated with the University of Bonn and offers a stimulating research environment through its international network, workshops and conferences, data service, project support, research visits and doctoral program. IZA engages in (i) original and internationally competitive research in all fields of labor economics, (ii) development of policy concepts, and (iii) dissemination of research results and concepts to the interested public.

IZA Discussion Papers often represent preliminary work and are circulated to encourage discussion. Citation of such a paper should account for its provisional character. A revised version may be available directly from the author. 


\section{ABSTRACT \\ Can Educational Expansion Improve Income Inequality in China? Evidences from the CHNS 1997 and 2006 Data}

Rapid education expansion and rising income inequality are two striking phenomena occurring in China during the transitional period. Using the China Health and Nutrition Survey (CHNS) data collected in 1997 and 2006, this paper studies how education affects individual earnings during the transitional process. We find that education accounts for only a small fraction of personal earnings and income gap between different groups. We analyze the underlying mechanism of the impact of education on earnings. More educated people tend to enter state-owned sectors, have a low probability of changing jobs in the labor market and work less time; all of these will have a pronounced impact on earning and income inequality. Quantile regression analysis shows that the low-income group's education return rate is lower, which helps little in narrowing income gap. We decompose the earning gap into four factors: population effect, price effect, labor choice effect and unobservable effect. In explaining the earning gap in China, the price effect is more important than the population effect. The labor choice effect is also significant. We conclude that increasing educational expenditure with no complementary measures such as reforming the education system and establishing a competitive labor market helps less in reducing income inequality.

JEL Classification: $\quad$ I20, J31, O15

Keywords: education expansion, income gap, rate of return to education, labor market

Corresponding author:

Guangjie Ning

Department of Economics

Nankai University

Tianjin 300071

China

E-mail: gjning@nankai.edu.cn 


\section{Introduction}

Education is often considered to exert significant impact on personal income. Education can improve an individual's skills and signal his or her innate productivity; so that workers with a high education attainment often receive high earnings. Expanding education investment is therefore believed to be one of the key measures to reduce poverty and income inequality, particularly in developing countries. As Ashenfelter and Rouse (2000, p.111) point out, "The school is a promising place to increase the skills and incomes of individuals. As a result, educational policies have the potential to decrease existing, and growing, inequalities in income". Heckman (2005) also declares that "human capital is the asset that ultimately determines the wealth of China. Fostering access to education will reduce inequality in the long run".

However, during the transitional process, China has witnessed contradictory phenomena. On the one hand, we observe rapid education expansion and even partial over-education. Thanks to the 9-year compulsory education policy initiated in 1986 , the enrollment rates of primary and secondary school rose ${ }^{1}$ and the average education attainment is quickly increasing too. Furthermore, the education expansion starting since the late 1990s takes place more in high education and high schools. According to the Educational Statistics Yearbook of China 2007, in 1997, the number of students in colleges and universities, high schools, secondary schools and primary schools in every 100 thousands population were $519,1978,4408$, and 11,287, respectively; the numbers in 2007 were 1924, 3409, 4364, and 8037, respectively. From the aspect of absolute quantity, the college enrollment and total number of students at high education schools in 1998 were 1.08 million and 3.41 million, respectively, while in 2005 the numbers reached 5.05 million and 15.62 million, with a growth rate of $368 \%$ and $358 \%$, respectively.

On the other hand, the unemployment rate of college graduates has been rising during recent years: only two thirds of college graduates can find a job by

\footnotetext{
${ }^{1}$ Particularly, the gross enrollment rate of secondary school rose considerably from $66.7 \%$ in 1990 to $98 \%$ in 2007(Ministry of Education of China, 2008).
} 
graduation. Particularly, students from poor families have more difficulties in job hunting. At the same time, even though China economy has kept a high growth rate (9.8 percent per year on average) for 30 years, income distribution has been deteriorating and the Gini coefficient for individual income has risen constantly to a relatively high level: from 0.382 in 1988 to 0.452 in 1995(Zhao et al., 1999), from 0.29 in 1981 to 0.39 in 1995 (World Bank, 1997), from 0.309 in 1981 to 0.447 in 2001(Ravallion and Chen, 2004), from 0.37 in 1991 to 0.44 in 2000(Benjamin et al., 2008). ${ }^{2}$

These seemingly contradictory facts lead us to ask two questions: Does education expansion contribute to the income inequality? What are the underlying mechanisms of education's impact on individual income? ${ }^{3}$

Lai(1997) and Bai(2004) demonstrate there exists an inverted U-curve relationship between education expansion and income inequality in China; however, their conclusions were based on macro data and the micro influencing mechanisms are not fully explored. Based on the CHNS micro data collected in 1997 and 2006, this paper aims to explore how education affects personal earnings during the transitional process in China. We are interested in the following questions: To what extent does the educational structure and distribution change lead to income inequality? To what extent does the rate of return to education (the higher return to higher education level) play a role? Does education attainment change the behavior of labor supply choice? Do different groups' rates of return to education vary? The new insights of this paper lie in: (1) we try to explore the underlying mechanisms of education's impact on income. For instance, how education attainment leads to change in labor supply behavior. Applying the quantile

\footnotetext{
${ }^{2}$ Given the different data sources and different measures, researchers can get different Gini coefficient results. However, they share the consensus that income inequality shows a tendency of rising since the inception of reforms in 1978. Apart from the Gini coefficient, there are three other measures: the Theil index, the mean log deviation, the transformed cofficient of variation. The Gini coefficient measure is widely used and more appropriate.

3 As wage income stands for a high proportion of residents' total income in China, in this paper we focus on wage income inequality closely connecting with education. Khan et al.(1999) mentioned other components of income and improper dis-equalizing policies such as housing and social safety net.
} 
regression method, we try to test whether the low-income group's education return rate is higher; consequently, whether schooling contributes to narrowing the income gap. Using the decomposition method based on the regression, we decompose changes in earning inequality into four factors: population effect (the distribution of education among population), price effect (the return rate to different education level), labor choice effect (differently educated labor group's different worktimes and unit choices) and unobservable factors (standing for family background and personal unobservable characteristics). (2) We establish a relatively comprehensive earning determination model considering factors such as labor mobility and health human capital. We also use several alternative income indicators to conduct a return rate estimation, not only of the annual wage income, but also of the total labor income per year; hourly earning is also used as a dependent variable to measure earning more precisely.

The paper is organized as follows. Section 2 presents some brief facts about education expansion and income inequality in developed and developing economies. Data source and empirical methodology are introduced in section 3. Section 4 presents the results of the estimate and factor decompositions, with some further discussion. The last section concludes with policy implications.

\section{Education Expansion and Income Inequality: literature review and some stylized facts}

There exist double-direction links between education attainment and income inequality. On the one hand, income inequality gives rise to education inequality. Even though education expands quickly in China, education attainment still varies across different groups and different regions. Inequality of accessibility to high school and high education increased over the period of 1989-2004(Saccone, 2008). In 2007, students graduating from college in Beijing amounted to 242,617, whereas in Qinghai, a province in western region, the number was only 15,483(Ministry of Education of China, 2008). Beijing's number of graduate students is over 15 times 
higher than Qinghai's. ${ }^{4}$ Guo and Jia(2009) argue that the local public education investment policy adopted in China is inefficient in promoting economic growth and narrowing wage differentials.

The social stratification literature points to strong effects of social background on educational attainment in modern societies. Education inequality is prevalent and poor families did not benefit much from education expansion and education marketization since the late 1990s in China (Ding, 2006). Education choice is endogenously determined. Children from poor families need to attend school more urgently to change their fates; however, there are economic barriers to continuing their education. ${ }^{5}$ Therefore, income inequality leads to education inequality and education inequality further brings forth even serious income inequality in the future (Yang, et al., 2008).

Other researchers argue that poor children (not the poorest) are not less educated, on the contrary, they might have been over-educated. Patrinos(1997) finds that in Greece the proportion of those overeducated that are from the lower classes is high (54 percent), although this varies by specialization. The reasons for over-education lie in that poor students have disadvantage in social capital network which is a crucial factor of obtaining good jobs in a relational society (Zhang, et al., 2009). In turn, they have to resort to a higher degree of education to signal their ability. As a result, over-educated persons are more likely to come from the lower classes and to migrate across the labor markets.

Furthermore, the existing industry wage gap (which is related to income distribution in the labor market) also motivates students to crowd into the so-called populous

\footnotetext{
${ }^{4}$ By contrast, according to China Statistical Yearbook 2008 (National Bureau of Statistics of China, 2008), Beijing's population at the end of 2007 is only about 3 times that of Qinghai's (16.33 million and 5.52 million, respectively).

5 Though education loans to some extent helped some poor students to continue their education, the application scope is still limited and credit constraint is obvious, the education burdens of poor families have not been considerably alleviated. Willen et al.(2004) show, however, that making education more affordable can increase income inequality. The mechanism that drives their results is a combination of credit constraints and the "signaling" role of education. Hence, this kind of income inequality is acceptable.
} 
majors of study such as finance, regardless of their innate talents and productivities. As skilled workers could not obtain good payment, technical or vocational education is backward and general-purpose high education is relatively redundant in China. Consequently, there is an over-supply of graduates in humanities and social science and a shortage of technical experts on the labor market. Though working-age workers are over-supplied, skilled workers are becoming scarce in recent years, which cannot meet the need of upgrading technology. In monopoly industries, employees are well-paid because of the high monopoly rents. Even though working in this industry does not necessarily require a high education level, firms often recruit new employees by setting up a high education requirement entrance threshold. Biased economic development strategy also leads to income gaps between occupations (Irizarry, 1980). There is good payment in special fields linked closely to foreign capital orientation policies in developing countries, such as foreign language, which also results in over-crowding in these fields. On the other hand, as they are depending heavily on developed countries' technology, developing countries do not demand more graduate students in science and technology and many educated labors are experiencing the process of deskilling.

Conversely, the distribution of education can influence income distribution (Gregorio and Lee, 2002). Consequently, education inequality gives rise to income inequality. According to the World Bank's statistics, the Gini coefficient of education in China was 0.37 in 2000; however, the Gini coefficient of income reached 0.45 in 2001, suggesting that education inequality alone cannot explain the whole income inequality.

Some attribute the rising income inequality in many countries to the increased return to high education level or convex return. Changes in the relative earnings among educational groups are always the leading force behind changes in inequality in Mexico (Legovini et al., 2005; Lopes-Acevedo, 2006).Ferreira et al.(2006) also find that the rising inequality in Brazil in the 1980s appears to have been driven by increases in the educational attainment of the population in a context of convex returns. In China the average return rate to schooling keeps rising and the return 
rates for different education categories have also been increasing, with much higher return rate for higher education levels (Lai, 1999; Li, 2003; Li and Ding, 2003; Li and Heckman, 2004). People having a lower education attainment benefit from absolute income increase; however, compared to those with a higher education level, the income gap is enlarged. Why do the highly educated obtain a much higher return? Does this relate to skill-biased technological change occurring in China or to other reasons, such as exploitation? If their higher wages cannot be fully compensated by their productivity, the income distribution becomes distorted. ${ }^{6}$

Even though poor students obtain the appropriate education, can they reap sufficient benefits of the investment in schooling? If not, then the income distribution pattern will not improve or even deteriorate. Education becomes more important in determining the choices of sectors and occupations in developing countries. Many students with a high degree try to seek a good job in the public sector; however, a high degree alone does not guarantee a government job if a student has no social capital network in relational society. Chen and Feng (2008) find that parents' education affects children's wage not only through human capital accumulation but also through the nepotism in the labor market. Public sector employees in Djibouti are more likely to be male and to come from the elite class with parents in the public sector (Casero and Seshan, 2006). In fact, job competition and over-education do not have beneficial influences on the disadvantaged; on the contrary, it discourages them from self-employment and the forming of entrepreneurship.

Furthermore, income inequality also exists among people with the same education attainment (Hoxby and Terry, 1999; Lemieux, 2006). Is this related to a difference in ability? Or are the lucky ones that have a good job selected randomly? Did Schooling change the ability distribution, or does it only play a signal role so that the income distribution will not improve? Using quantile regression, Martins and Pereira (2004) find a stylized fact over 16 developed countries: returns to schooling

\footnotetext{
${ }^{6}$ On the other hand, it needs to be noted that the higher return to high education in China is also associated with self-selection problems, as only those who pass the rigid entrance exam (more capable) can enter college.
} 
increase over the wage distribution. To put it differently, the earnings increment associated with schooling is higher for those individuals whose unobservable characteristics place them at the top of the conditional wage distribution. Heckman (2000) argues that it is non-cognitive skill that plays a role. We are interested in to what extent the income is determined by human capital obtained in school and to what extent by non-cognitive skills closely associated with the social background. Poor students perform the same or even better than others, but their labor market prospects are lower.

Over-education gives rise to further enlarged income inequality. People who are over-educated earn less. In a few studies the coefficient of over-education is found to be negative and statistically significant (Sicherman, 1991; Patrinos, 1997; Borghans and Grip, 2000). In recent years it became more difficult for undergraduate and graduate students to find a good job in China. Some of them have to condescend to take a job in which their education quality cannot be fully applied, which inflicts their education returns. In this sense, the over-education choice is endogenously selected.

All of the problems above are closely linked to the imperfect labor market. Partial over-education is taking place and educated labors congest in large eastern cities. Education expansion contributes less to the convergence of regional income. Cities in China are still not fully integrated so that they can be considered as local labor markets in which city-specific characteristics lead to differential returns to education, as Yang (2005) argues. Owing to the wage gap existing between regions, students from western areas will be reluctant to work in their hometown. In order to obtain a good job in the eastern area, they must further their education.

Regarding the education's signal function, it partly fails because of the irrational examination system and the enterprises' limited or failed screening activities (Ning, 2006). Therefore, pooling equilibrium arises, resulting in the skill heterogeneity of workers acquiring the same diploma. In order to stand out, highly skilled labor has to invest more in education. Why are firms not willing to screen? They care more about the cost and benefit of screening and the high costs discourage them. 
In the aspect of education quality, the lower education quality poor students experienced can only bring them lower returns to education. Education expansion leads to some problems. College enrollment expands sharply and education resource per capita is reduced, so that the quality of the graduates declines in recent years. Compared to college graduates 10 years ago, the skill decreasing in the recent cohort is evident. Unqualified graduates suffer from more income loss.

Above all, we find out the complex relationship between education and income distribution, including the role of education structure, return rates to different education level, education's signal and human capital improvement functions and quality of education. In this paper, we will explore and explain these problems by conducting some empirical analyses.

\section{Data Source and Methodology}

Our empirical analysis relies on data from the China Health and Nutrition Survey (CHNS) for the years 1997 and 2006, conducted by the Carolina Population Center at the University of North Carolina at Chapel Hill and the National Institute of Nutrition and Food Safety at the Chinese Center for Disease Control and Prevention. Although the main aim of the survey is to investigate rural and urban residents' health and nutrition conditions in China, other related information on education and income (previous year) is also reported, which is very useful for our study. CHNS data covers 9 provinces: Heilongjiang, Jiangsu, Shandong, Guizhou, Guangxi, Hubei, Henan, Hunan and Liaoning. ${ }^{7}$ Richer and poorer provinces are excluded from the sample so that the sampled provinces are representative of a typical province in China. The 1997 survey covers 16 cities with 128 neighborhoods and 32 counties with 256 villages; the 2006 survey covers 18 cities with 216 neighborhoods and 36 counties with 432 villages. The sample sizes are 14,399 and 9788 adults (age 18 and older) for 1997 and 2006, respectively. However, only 2875 in 1997 and 2096 persons in 2006 held jobs and provided wage information. ${ }^{8}$ Other information,

\footnotetext{
${ }^{7}$ In 1997 survey, Liaoning is not included, only 8 provinces being covered.

${ }^{8}$ Only the people who hold jobs and earn wage enter our sample, so that the problems of selection
} 
such as age, gender, household registration, occupation category, and types of working unit, is also reported. We select these 2 years to make comparisons and test the impact of education expansion since the late 1990s on income distribution.

Firstly, let us look at some statistics for the key variables: the average education attainment of the interviewed adults rises from 6.23 years in 1997 to 9.49 years in 2006. As for individuals with jobs, the figure rises from 10.39 years in 1997 to 11.22 years in 2006. Their average experience rises from 19.46 years in 1997 to 21.98 years in 2006. The average annual labor income increases sharply, from 5996.71 yuan in 1996 to $15,286.05$ yuan in $2005,{ }^{9}$ with a wider dispersion in 2005 (standard deviation expands from 5656 in 1996 to 27,964 in 2005).

From a microeconomic point of view, changes in worker's earnings can result from changes in decisions regarding labor force participation and working unit choice, in demographic characteristics, and in the returns to those characteristics. The approach we use is designed to measure the relative importance of these different sources of income change. We assume that earnings are a function of skills measured by education and experience, controlling for gender, household registration (urban or rural residents), working unit characteristics and other related variables. We specify the econometric model as follows:

$\log ($ wage $)=c+\beta_{1} e d u c+\beta_{2} \exp e+\beta_{3} \exp e^{2}+\beta_{4}$ gender $+\beta_{5}$ hukou $+\beta_{6}$ moblity $+\beta_{7}$ unit $+\beta_{8}$ unitscale $+\beta_{9} i l \ln e s s+\varepsilon$

where wage denotes the individual wage earnings of the previous year (the year 1996 and the year 2005), educ stands for years of schooling, expe captures the work experience (subtracting educ plus 7 from age), gender is the gender dummy variable ( 1 for male and 0 for female), hukou is the dummy variable of household registration ( 1 for urban and 0 for rural), mobility is a dummy variable

bias might arise. We should therefore use some appropriate approaches to cope with these in our future research.

${ }^{9}$ Average real earning measured in 1996 yuan is $14,166.87$. 
to represent labor mobility, it equals 1 if the individual changed job after 1993 or 2004, unit captures the type of work unit. There are 8 types of units, including government department, state service/institution, state-owned enterprises, small collective enterprise (such as township-owned), large collective enterprise (such as owned by county, city, province), family contract farming, private, individual enterprise and three-capital enterprise (owned by foreigners, overseas Chinese and joint venture). We define the first three types as 1 and the other 5 types as 0 in order to find out if working in the state-owned sector has significant positive impact on earning. unitscale is the dummy variable for size of work unit, it equals 1 if the number of employees in the work unit is more than 100 and 0 otherwise. The coefficient of this variable can tell us whether the scale of work unit (or monopoly status) contributes to high earning. il $\ln e s s$ is the health human capital indicator reached by asking whether during the past 3 months the respondents have had any difficulty carrying out their daily activities and work or studies due to illness, the answer yes is signed as 1 , no is $0 . \varepsilon$ is an error term. ${ }^{10}$

The dependent variables also include annual earnings (income, monthly wage and subsidies multiplied by working month, ${ }^{11}$ then plus yearly bonus), hourly earnings (income / worktime, total annual earning divided by working hours per year). For the education indicator, we will also evaluate returns to different educational categories through dummy variables such as secondary school, high school, technical or vocational degree, university or college degree and higher(using primary school education level as reference group). For unit categories, likewise, we have several dummy variables to calculate the return to individual unit type. Considering the possibility that a high educated person is more likely to enter the

\footnotetext{
${ }^{10}$ The omission of an individual's ability in the OLS regression may result in a biased and inconsistent estimate of the returns coefficient due to positive correlation between schooling and ability. Three strategies are used to deal with this ability bias, namely the instrumental variable approach, the fixed effect method, and direct measurement of ability. However, each of these approaches has stringent data requirements (see Yang, 2005). CHNS does not have sufficiently enough data to permit careful corrections for the ability bias.

${ }^{11}$ In other case, 12 is multiplied by assuming wage and subsidies are automatically obtained every month without being influenced by worktime.
} 
state unit, we replace the education category variables with occupation type variables. There are 12 occupation categories: senior professional/technical worker (doctor, professor, lawyer, architect, engineer); junior professional/technical worker (midwife, nurse, teacher, editor, photographer); administration/executive/manager (working proprietor, government official, section chief, department or bureau director, administrative cadre, village leader); office staff(secretary, office helper); farmer, fisherman, hunter; skilled worker(foreman, group leader, craftsman); non-skilled worker(ordinary laborer, logger); army officer, police officer; ordinary soldier, policeman; driver; service worker(housekeeper, cook, waiter, doorkeeper, hairdresser, counter salesperson, launderer, child care worker); athlete, actor, musician.

Eq. (1) is a commonly used but highly restrictive human capital model, as it assumes that the returns to education and experience are the same for all workers. If the schooling-related earnings increment were not the same across the income distribution, then schooling would impact upon within-levels income inequality, as income distributions conditional on different levels of schooling would differ not only in their locations, but in their dispersions as well. In this case, an OLS regression is not informative and quantile regression model should be applied. We will use quantile regression in section 4 to test if education's return rates across the income distribution are different, which is crucial for studying education's role in reducing income inequality.

We also test the role of different factors (labor force participation and working unit choice, demographic characteristics, and the returns to those characteristics) in income differential. A decomposition method is applied here. The income $y_{i t}$ of individual $i$ observed at time $t$ is assumed to depend on four sets of variables: the observable personal characteristics $x$, unobservable characteristics $\mathcal{E}$, the set of prices and labor-remuneration rates $\beta$, and a set of parameters defining the labor force participation and working time $\lambda: y_{i t}=Y\left(x_{i t}, \varepsilon_{i t}, \beta_{i t}, \lambda_{i t}\right)$.

Like the well-known Oaxaca-Blinder methodology, the difference between two 
group's income can then be decomposed into price effect (the effect of changes in the returns to education and experience), population effect (the effect of changes in the distribution of education, experience, and etc), labor choice effect (the effect of changes in the working time and unit choice) and unobservable factor effect (the effect of changes in the distribution of the errors in the earnings equations). The decomposition can then be stated as

$$
\begin{aligned}
& \Delta y=\left[y\left(\beta_{j}, x_{j}, \lambda_{j}, \mathcal{E}_{j}\right)-y\left(\beta_{i}, x_{j}, \lambda_{j}, \mathcal{E}_{j}\right)\right]+\left[y\left(\beta_{i}, x_{j}, \lambda_{j}, \varepsilon_{j}\right)-y\left(\beta_{i}, x_{i}, \lambda_{j}, \mathcal{E}_{j}\right)\right] \\
& +\left[y\left(\beta_{i}, x_{i}, \lambda_{j}, \varepsilon_{j}\right)-y\left(\beta_{i}, x_{i}, \lambda_{i}, \varepsilon_{j}\right)\right]+\left[y\left(\beta_{i}, x_{i}, \lambda_{i}, \varepsilon_{j}\right)-y\left(\beta_{i}, x_{i}, \lambda_{i}, \varepsilon_{i}\right)\right]
\end{aligned}
$$

The four parts in this equation represent an exact "sequential" decomposition of price effect, population effect, labor-choice effect, and unobservable factor effects.

\section{Econometric results and discussion}

\subsection{The impact of education on income}

Table1 Determinants of various types of income

Firstly, we examine the impact of education attainment on earnings. As shown in Table 1, applying the Mincer function in 2006 data, we obtain different return rates to years of schooling where different income types are used as dependent variables. When wage is used as the dependent variable in column (1), the rate of return to education is $7.9 \%$. When annual earning is used as dependent variable in column (3), the return rate rises to $11.3 \%$. In the case of hourly earning in column (5), the return rate is the highest, $12.5 \% .^{12}$ This implies that more educated workers have more advantage in bonus distribution than in wage distribution. Furthermore, less educated workers have to work more time to make a living. When we control for other individual characteristics such as gender, hukou, unit type and mobility in column (2), (4) and (6), the absolute values of education return rate become lower (which implies that ignoring the controlling variables will overestimate the

\footnotetext{
${ }^{12}$ As Li (2003) states, previous works using annual earnings instead of hourly wages bias the return rate estimates downward.
} 
education return rate), but the relative scale and rank do not change. As shown in the last two columns of Table 1, the return rate to education in 1996 is only between 3.6 and $3.7 \%$. Our results are comparable to previous studies using other data sources. For example, using 1988 and 1995 data from a national household survey, Yang (2005) finds that the estimated rates of return at the city level increased from 3.1 to $5.1 \%$ between those 2 years. Based on the survey conducted by the Chinese Academy of Social Science (CASS), Luo's study (2007) shows that return rate to education was $6.76 \%$ in 2002 . On average, compared to the 1990 s and early in 2000s, the return rate to education increased as the transitional process deepened in China, which will exert an impact on income inequality. In addition, the earnings increase as the experience grows, with a diminishing return rate, which conforms to the traditional human capital theory. The return rate to experience also remained relatively stable over the 9-year period.

There are some other noticeable findings in the income regression functions in Table 1. In 2005, a male worker earned about a range of $23.8-26.0 \%$ more than a female one. A worker with urban household registration earned about 7.5-11.5\% more than a worker coming from a rural area. This might suggest that gender discrimination and social status discrimination exist in the labor market. Regarding labor mobility, contrary to human capital theory and other empirical studies, people who changed their job suffer from income loss rather than enjoy income gain. ${ }^{13}$ This may be because most of those who changed jobs were involuntary unemployed during the period of economic recession or state-owned enterprise restructuring reform. It might also be due to the fact that labor mobility is very low and changing jobs is a negative signal to the employers in China. As expected, working in state unit and unit employing a large number of workers brought a worker more pay-off in 2005, indicating that unit monopoly has a positive impact on earning. However, in 1996, working in a state enterprise or institute could not ensure wage premium, even inflicting some loss, despite this not being statistically significant. This is attributed

${ }^{13}$ In 1996, there was some income premium from job change, but this was not statistically significant. 
to the state-owned enterprises' adverse conditions during the reforming process in the 1990s. It can also be seen that people who had any difficulty carrying out work during the past 3 months due to illness suffered a wage loss, but the impacts are not statistically significant in total income and hourly earning models. ${ }^{14}$ The health human capital theory is only partially supported.

So far we still do not know the exact ways in which education influence the income. According to the classical human capital theory, more educated workers have a higher labor-force participation rate and works longer time, more prone to move in labor markets to seek for better jobs, more likely to enter the state-owned or monopoly sector to earn high wages, having a higher probability of escaping from illness and maintaining a stable income level. Do all these hold true in China?

Table 2 How does education affect income: the underlying mechanisms(2005)

As shown in column (1) of Table 2, the more educated workers work less time, possibly because they have an inflexible time schedule or the higher wage rates enable them to enjoy more leisure time. Using wage rate (income hourly) as explanatory variable (other variables are unit scale and gender), we find that the coefficient of wage rate is negative; ${ }^{15}$ in other words, the income effect dominates the substitution effect. Moreover, workers in the state-owned sector work less time; however, those in large-scale units work more time. People holding urban household registrations work less time. A logit model is estimated in column (2) and shows that the more educated are more likely to enter state-owned sector. Urban household registration holders and male workers are also more likely to join in the state-owned sector. Column (3) shows that the more educated are less likely to

\footnotetext{
${ }^{14}$ Because of its insignificance, we omit the health variable in the total income and hourly earning models in Table 1. 15

$\log ($ worktime $)=7.783^{\text {*** }}-0.141^{\text {**** }} \log ($ income $/$ worktime $)+0.060^{\text {***** }}$ gender $+0.037^{\text {*** }}$ unitscale ; adjusted $\mathrm{R}^{2}=0.066$, observations $=1823$.
} 
move in the labor market, which contradicts classical human capital theory. There still exist some barriers to migration in the labor market restricting the more educated to move. It is those who are less educated that move frequently in the secondary labor market in China. In column (4), it seems that the more educated are less likely to suffer from work loss due to illness, but the coefficient is not statistically significant. In summary, Table 2 illustrates that the mechanisms of worktime and sector selection are sufficiently confirmed, while the mobility and health mechanisms are insignificant.

Table3 Education category, unit and occupational choice and income

In order to investigate the role of education role in income determination more precisely, we estimate the return to different education categories. Column (1) of Table 3 shows that in 2005, compared to the return to primary school, the return to secondary school, high school, technical or vocational degree, and college or university degree and above are $16.3 \%, 31.6 \%, 48.1 \%$, and $76.9 \%$ higher, respectively. Whereas column (4) shows that in 1996, compared to the return to primary school, the return to secondary school, high school, technical or vocational degree, and college or university degree and above are $3.2 \%$ lower (though the effect is not significant), $8.1 \%$ higher, $2.3 \%$ higher (not significant), and $12.1 \%$ higher, respectively. The return gap between primary school and college or university degree was enlarged substantially in recent years, which leads to an obvious income inequality ${ }^{16}$. Are the different return rates rational? One may attribute this to the increased demand for technology-biased skill and relative limited supply of educated labor in China. However, we should still be cautious about the overpayment for the highly educated owing to the imperfectly competitive labor market. This implies that obtaining just a primary or secondary education

\footnotetext{
${ }^{16}$ By contrast, through international empirical study, Trostel(2004) indicates that human capital production displays significant increasing returns at low levels of educational attainment, and significant decreasing returns at high levels of educational attainment.
} 
helps less in the case of rising education return rate. It can also be found in column(1) that in 2005, compared to working in the government department, those working in state service/institutions, small collective enterprises, large collective enterprises, family contract farming, and private and individual enterprises earn $11.8 \%$ higher, $18.3 \%$ less, $28.1 \%$ less, $49.5 \%$ less, $13.2 \%$ less, respectively. Overall, workers in the state-owned sector have a high wage premium. In addition, working more time will significantly increase the yearly income. ${ }^{17}$

Since education level and unit type might be correlated (more educated persons are more likely to enter the state-owned sector), column (2) replaces the education variables with occupation variables to avoid the multicollinearity problem. Compared to senior professional/technical workers, the payment of other occupations is less, especially that of non-skilled occupations and service occupations having low education requirement. However, the problem of multicollinearity is not serious by observing the correlation matrix. Therefore, the model in column (3) has a full set of variables. Controlling for occupational variables, the return gap between different education categories still exists but narrows. The return rate to education reduces at every education level, implying the weakened role of education in reducing poverty. Unit and occupation choice are also important for income gain.

Table 4 Different factors' contribution to income $(\%, 2005)$

Based on the regression function of full sample, we test the effects of different factors on income. The calculation method is the mean value of explanatory variable multiplied by the return rate, then divided by the mean value of logarithm of income. Column (1) of Table 4 presents the results using working months to calculate income. We also use 12 months to calculate annual income, considering wage or other income is automatically received regardless of working time. The results are

\footnotetext{
${ }^{17}$ As people lay more emphasis on total income in developing countries, we use income per year as the dependent variables in the following analysis.
} 
listed in column (2). In both cases, the variable of education accounts only for approximately $9.6-10.9 \%$ of income. Personal characteristics and unit type also explain a small proportion. Worktime is an important factor. The residual in the regression function represents rewards for unobservable ability and family background, which is also a great share of income.

\subsection{Education and income distribution: quantile regression results}

The income gap is large even for people with the same education level. This probably weakens the education's role in reducing income inequality. Taking the individuals with college and university degrees as an example, their average annual income in 2005 is 21,030.54 yuan, the maximum reaching 216,000 yuan and the minimum only 1200 yuan. The standard deviation is 19,209.77. The income equation estimation result is listed as below, with an adjusted $R^{2}$ of 0.23 and sample size of 404.

$$
\begin{aligned}
& \log (\text { income })=3.983+0.139^{* * *} \text { gender }+0.223^{*} \text { hukou }+0.015^{*} \exp e-0.00015 \exp e^{2} \\
& +0.214^{* * * *} \text { unit }+0.124^{* * *} \text { unitscale }+0.676^{* * * *} \log (\text { worktime })-0.028 \text { mobility }-0.191 \text { il } \ln \text { ess }
\end{aligned}
$$

As shown in the equation (3), personal characteristics like gender and hukou influence income; unit and unit scale also play a great role. Having a high degree is not sufficient to guarantee a high income. Only entering a monopoly sector through social network can ensure a high and stable income.

To test the profound relationship between education attainment and income inequality, we estimate a quantile regression model to analyze the return rate at different income distribution points. The dependent variable is yearly income. The independent variables include education year, years of experience, square of years of experience, unit, unit scale, gender, mobility dummy, household registration, illness, and worktime. The sample size is 1726 . The estimation results are shown in Fig.1. It can be found that the education year's coefficients display a tendency of slightly downward sloping as the quantile point moves up, but turn upward at the fifth and ninth quantile points, suggesting a complex relationship between education attainment and income inequality. In some high-income distribution points, the 
return rates are relatively high, implying that education expansion has the impact of enlarging the income gap. Applying the CHNS data of 2004 (the sample size is 1931), Liu(2008) conducts a quantile regression and finds that the return rates at 0.1 , $0.25,0.5,0.75$ and 0.9 point are $7.22 \%, 6.8 \%, 6.74 \%, 5.58 \%$, and $5.24 \%$, respectively, suggesting that the return rate has a tendency of decreasing with the income. Our results are different from Liu's, as we use 2006 data and more explanatory variables are included.

Fig.1. The return rate to education at different quantile point (education year, 2005)

We also estimate returns to different educational categories at different quantile points, using primary school education level as reference group. The explanatory variables of education are dummy variable of secondary school, high school, technical or vocational degree, and college or university degree and higher. Other independent variables include years of experience, square of years of experience, unit, unit scale, gender, mobility dummy, household registration, illness, and work time. The sample size is 1726 . Fig.2 plots the results; the insignificant coefficients are not shown in the figure.

Fig. 2. Education's return at different quantile point (education category, 2005)

It can be seen in Fig. 2 that the returns to secondary school are insignificant at 0.1 , 0.2 , and 0.9 quantile points, suggesting that for certain group (to become the low-income group ${ }^{18}$ ), obtaining only a secondary school diploma helps less in improving their income status. This implication is also in accordance with the basic observation that some low-income families often complain that the compulsory

\footnotetext{
${ }^{18}$ Martins and Pereira (2004) attribute the lower wage distribution (lower quantile point) to the workers' lower skill and explore the reasons from the aspect of over-education, ability and school quality. As mentioned in section 2, all these reasons exist in China. However, most importantly in China, the imperfect labor market restricts competition and prevents the similarly capable labors' education return rate from equalizing.
} 
secondary schooling played little role in improving their income and reducing poverty. For high school, the return rate is insignificant at 0.1 point, then becomes rising, showing that obtaining a high school degree is more beneficial for the middle- and high-income group, which will also enlarge the income gap. The technical or vocational degree's returns are higher at low and middle quantile points, as through the technical or vocational education students can learn some practical skills closely related to their future career. For the low-income group, obtaining such education contributes to their income gain, but the return difference is small. ${ }^{19}$ College or university degree's return rates also show the tendency of downward sloping, which helps improve income distribution, but at 0.9 point it starts rising again.

Overall, roughly speaking, for the low-income group, obtaining a secondary or high school degree helps less in improving their income condition, while obtaining technical or university degree can reduce the income inequality.

\subsection{Decomposition of income gap}

Table 5 Mean value and coefficient of variable (full sample and low-income group, 2005)

To provide corroborating evidence, we decompose different group's earning gap into four factors: population effect, price effect, labor choice effect, and unobservable effect. As for the role of education, we want to examine the income impact of education distribution among population, return rate to education, different group's participation rate and working unit choice, and personal capability or family background, respectively. Table 5 explains the income gap between the full sample and the low-income group ${ }^{20}$ and the influencing factors. Insignificant results are not reported. We list the explanatory variables' mean value and

\footnotetext{
${ }^{19}$ In the case of Taiwan, obtaining a higher secondary education (vocational) can also earn a higher income than that of ordinary secondary education. See Bourguignon, et al.(2005).

${ }^{20}$ We divide the full sample into three sub-samples according to worker's earning level.
} 
coefficients. The income gap between full sample and low-income group is the difference of their mean values of logarithm of incomes, which are attributed to various factors. Taking education year as an example, low-income group's education attainment is lower $(9.75<11.21$, population effect), and its return rate is lower $(0.029<0.091$, price effect). Hence, educational structure difference can explain only $16.6 \%\left((11.21-9.75) * 0.091^{21} /(9.36-8.56)\right)$ of the income gap, while the price effect, the difference of return to education, accounts for $75.6 \%$ $\left(9.75^{*}(0.091-0.029)^{22} /(9.36-8.56)\right)$ of the income gap. This also reflects the fact that only improving the poor's education attainment without changing the income distribution in labor markets is not sufficient. Concerning the role of gender, the low-income group is composed of more female workers, and male workers cannot earn much more than their counterparts in the full sample. It is also true that the price effect exceeds the population effect $(8.46 \%>3.9 \%)$. Worktime difference accounts for the greatest proportion of the income gap, not only because people from the low-income group work for less time, but also because the return to worktime is lower, which is much more important for the income gap (114.85\%>8.39\%). Using the CHNS 1989-2000 data, Chen and Wang (2006) decompose the wage functions into quantity effect (similar to the population effect here), price effect and unobservable effect and find that much of the rise in income gap between low-income and high-income group can be attributed to the price effect. $^{23}$ Considering the labor choice effect, precedent analysis in this paper suggests that more educated people choose to work less time in China, thus narrowing the income gap. Meanwhile, Table 5 shows that labor choice connecting with worktime works in an opposite direction, enlarging the income gap. Unit scale

\footnotetext{
21 Here we only consider the income gap resulting from the low-income group's lower education year, holding its education return rate same as the full sample's.

${ }^{22}$ Here we consider the income gap resulting from the difference of return rates, assuming obtaining the education year of low-income group.

23 Similarly, Lemieux (2006) points out that most of the increase in wage inequality between 1973 and 2005 in the U. S. is due to dramatic increases in the return to postsecondary education. Changes in wage inequality are increasingly concentrated at the very top end of the wage distribution.
} 
has a small impact of equalizing income between the groups, contrary to the classical labor choice effect prediction. ${ }^{24}$ The unobservable effect also takes a high proportion $(23.75 \%,(0.59-0.40) /(9.36-8.56))$, implying that unobservable ability and family background exert a great effect on income distribution.

\section{Summary}

Using the CHNS data collected in 1997 and 2006, this paper explores how education affected personal income during the transitional process in China. We find that education explains only a small fraction of personal income and income gap across different income groups. However, more educated people tend to work in the state-owned sector, have a low probability of moving in the labor market and work less time, which have a pronounced impact on income inequality. Quantile regression results indicate that the low-income group's education return rate is lower, particularly at the secondary school and high school level, which helps little in narrowing the income gap. We decompose changes in the earning gap into four factors: population effect (the distribution of education among population), price effect (the return to different education level), labor choice effect (differently educated labor group's different participation rates and working unit choices) and unobservable effect (personal ability and family background). In explaining the income gap in China, price effect and labor choice effect are large relative to population effect.

Our study can shed light on education development in other transitional developing countries. The policy implication is that increasing education expenditure with no complementary measures such as reforming the education system and establishing a competitive labor market helps little in reducing income inequality. In the aspect of education reform, government should make access to education easier and reduce education inequality, ${ }^{25}$ improve schooling quality and reduce partial over-education,

\footnotetext{
${ }^{24}$ Here, the impacts of worktime and unit choice (including price effect and population effect) are called labor choice effect.

${ }^{25}$ Ram (1990) found that educational inequality first increases, and, after reaching a peak, starts declining in later phases of educational expansion. However, we should take some active measures
} 
and establish a social network between employer and school to help the employer screen capable employees(Rosenbaum and Blinder, 1997). More importantly, constructing a competitive labor market, encouraging workers to flow freely, adjusting different workers' education return rate to their true productivity, and adjusting wages among industries or sectors through marketization(workers with similar human capital should earn similar wages, even though working in different industries or sectors ${ }^{26}$ ) are identified as important measures to narrow the income gap.

There are some limitations in our paper. The sample includes only 9 provinces, so we should be cautious about generalizing our conclusion to the whole country. ${ }^{27}$ Expanding the sample size, enlarging the time scope of analysis and decomposing the Gini coefficient differential of different years are the agendas of our further work.

\section{References}

Ashenfelter, O., Rouse, C., 2000. Schooling, Intelligence and Income in America.

In: Arrow, K., Bowles, S., Durlauf, S. (Eds.), Meritocracy and Economic Inequality. Princeton University Press, Princeton, NJ, pp.89-117.

Bai X., 2004. Education and Income Inequality: China Empirical Study. Management World 20(6), 53-58 [in Chinese].

Benjamin, D., Brandt, L., Giles J., Wang, S., 2008. Income Inequality During China’s Economic Transition. In: Brandt, L., Rawski, T. G.(Eds.), China’s Great Economic Transformation. Cambridge University Press, Cambridge, pp.729-775.

\footnotetext{
to reduce education inequality, which is a necessary condition (if not a sufficient one) for income equality.

${ }^{26}$ In a fully integrated labor market, returns to education adjusted to school quality and the composition of industries should be equalized across regions as the educated workforce search for and move to jobs offering the highest pay. Increasing returns to the public sector which has been immune to marketization until recently in China, can hardly be attributed to marketization.

${ }^{27}$ Yang (2005) found that the dispersion in schooling returns across cities in China is quite large. Market integration and labor mobility would serve as equilibrating forces to reduce regional disparities in returns to education.
} 
Borghans, L., Grip, A. D., 2000. Skills and Low pay: upgrading or over-education? In: Gregory M., Salverda, W., Bazen S.(Eds.), Labor Market Inequalities: Problems and policies of low-wage employment in international perspective. Oxford University Press, Oxford, pp.198-224.

Bourguignon, F., Fournier, M., Gurgand, M., 2005. Distribution, Development, and Education in Taiwan, China, 1979-1994. In: Bourguignon, F., Ferreira, F.H.G., Lustig, N.(Eds.), The Microeconomics of Income Distribution Dynamics in East Asia and Latin America. World Bank and Oxford University Press, New York, pp.313-356.

Casero, P., A., Seshan, G., 2006. Public-Private Sector Wage Differentials and Returns to Education in Djibouti. Policy Research Working Paper 3923, World Bank, Washington, DC.

Chen, Y., Wang, Z., 2006. The Evolution of China's Income Distribution from 1989 to 2000: Regional Inequality, Urban-rural Gap and Human Capital. In: Cai, F., Wan, G.(Eds.), The Income Differentials and Poverty During China's the Transitional Period. Social Science Literature Press, Beijing, [in Chinese], pp.150-164.

Chen, Y., Feng, S., 2008. Parental Education and Children's Wage: Evidence from China. Available at:

http://www.wise.xmu.edu.cn/Activity/Labor2008/Files/papers/p31_Yuanyuan\%20C hen_Parental\%20Education\%20and\%20Children's\%20Wages\%20Evidence\%20fro m\%20China.pdf.

Ding, X., 2006. Scale Expansion and High Education Enrollment Opportunity Equality. Peking University Education Review 4(2), 24-33 [in Chinese].

Ferreira, F. H. G., Leite, P. G., Litchfield, J. A., 2006. The Rise and Fall of Brazilian Inequality 1981-2004. Policy Research Working Paper 3867, World Bank, Washington, DC.

Gregorio, J. D., Lee, J. W., 2002. Education and Income Distribution: New Evidence from Cross- country Data. Review of Income and Wealth 48, 395-416.

Guo, Q., Jia, J., 2009. Public Education Policy, Economic Growth and Human Capital Premium. Economic Research Journal 44(10), 22-35 [in Chinese]. 
Heckman, J., 2000. Policies to Foster Human Capital. Research in Economics 54, $3-56$.

Heckman, J., 2005. China's Human Capital Investment. China Economic Review 16, $50-70$.

Hoxby, C. M., Terry, B., 1999. Explaining Rising Income and Wage Inequality Among the College-educated. NBER Working Paper 6873, Cambridge, MA.

Irizarry, R. L., 1980. Overeducation and Unemployment in the Third World: the Paradoxes of Dependent Industrialization. Comparative Education Review 24, 338-352.

Khan, A., R., Griffin, K., Riskin, C., 1999. Income Distribution in Urban China during the Period of Economic Reform and Globalization. The American Economic Review Papers and Proceedings 89, 296-300.

Lai, D., 1997. Education Expansion and Income Inequality. Economic Research Journal 32(10), 46-53 [in Chinese].

Lai, D., 1999. Education, Labor Market and Income Distribution. In: Zhao, R., Li, S., Riskin, C.(Eds.), Restudy on China Resident Income Distribution: Economic Reform and Developing Income Distribution. China Finance \& Economy Press, Beijing, pp.451-474. [in Chinese]

Legovini, A., Cesar, B., Nora, L., 2005. Can Education Explain Changes in Income Inequality in Mexico? In: Bourguignon, F., Ferreira, F.H.G., Lustig, N.(Eds.), The Microeconomics of Income Distribution Dynamics in East Asia and Latin America. World Bank and Oxford University Press, New York, pp.275-312.

Lemieux, T., 2006. Postsecondary Education and Increasing Wage Inequality. American Economic Review Paper and Proceedings 96, 195-199.

Li, H., 2003. Economic Transition and Returns to Education in China. Economics of Education Review 22, 317-328.

Li, S., Ding, S., 2003. The Long Trend of Return to Education in Urban China. China Social Science 24(6),58-72 [in Chinese].

Li, X., Heckman, J., 2004. Selection Bias, Comparative Advantage and Heterogeneous Return to Education: based on empirical study on China micro data. 
Economic Research Journal 39(4), 91-99 [in Chinese].

Liu, S., 2008. The Impact of Education and Experience on Chinese Resident's Income Distribution: basing on the empirical analysis of quantile regression and censored quantile regression. The Journal of Quantitative \& Technical Economics 25(4), 75-85 [in Chinese].

Lopes-Acevedo, Gladys, 2006. Mexico: Two Decades of the Evolution of Education and Inequality. Policy Research Working Paper 3919, World Bank, Washington, DC.

Luo, C., 2007. Return to Education and its Distribution in Urban China. Economic Research Journal 42(6), 119-130 [in Chinese].

Martins, P., S., Pereira, P., T., 2004. Does Education Reduce Wage Inequality? Quantile regression evidence from 16 countries. Labor Economics 11, 355-371. Ministry of Education of China, 2008. Educational Statistics Yearbook of China 2007. People's Education Press, Beijing (in Chinese).

National Bureau of Statistics of China, 2008. China Statistical Yearbook 2008.

China Statistics Press, Beijing (in Chinese).

Ning, G., 2006. Education's Signal Function and its Failure in Developing Countries. Tsinghua Education Study 16(5), 55-63 [in Chinese].

Patrinos, H., A., 1997. Overeducation in Greece. International Review of Education 43(2/3), 203-223.

Ram, R., 1990. Education Expansion and Schooling Inequality: International Evidence and Some Implication. The Review of Economics and Statistics 72, 266-274.

Ravallion, M., Chen, S., 2004. China's Uneven Progress against Poverty. Policy Research Working Paper Series 3408, World Bank, Washington, DC.

Rosenbaum, J. E., Blinder, A., 1997. Do Employer Really Need More Educated Youth? Sociology of Education 70, 68-85.

Saccone, D., 2008. Educational Inequality and Educational Poverty: the Chinese Case in the Period 1975-2004. Research Paper No.8/2008-GE, Department of Economics, University of Torino. 
Sicherman, N., 1991. Over-education" in the Labor Market. Journal of Labor Economics 9, 101-122.

Trostel, P., A., 2004. Returns to scale in producing human capital from schooling. Oxford Economic Papers 56, 461-484.

Willen, P., Hendel, I., Shapiro, J., 2004. Education Opportunity and Income Inequality. NBER Working Paper 10879. Cambridge, MA.

World Bank, 1997. China 2020: Sharing Rising Incomes, World Bank, Washington,DC.

Yang, D. T., 2005. Determinants of schooling returns during transition: Evidence from Chinese cities. Journal of Comparative Economics 33, 244-264.

Yang J., Huang X., Li X., 2008. The Educational Inequality and the Gap in Income Distribution: an Empirical Analysis on China. Management World 24(1), 38-47 [in Chinese].

Zhang, S., Zhang, G., Lai, Z., 2009. A Study on the Influence of Social Capital on University Graduates Employment: taking Huaqiao university as an example. Journal of Sichuan College of Education 25(6), 1-4 [in Chinese].

Zhao, R., Li, S., Riskin, C., 1999. Restudy on China Resident Income Distribution: Economic Reform and Developing Income Distribution. China Finance \& Economy Press, Beijing [in Chinese]. 


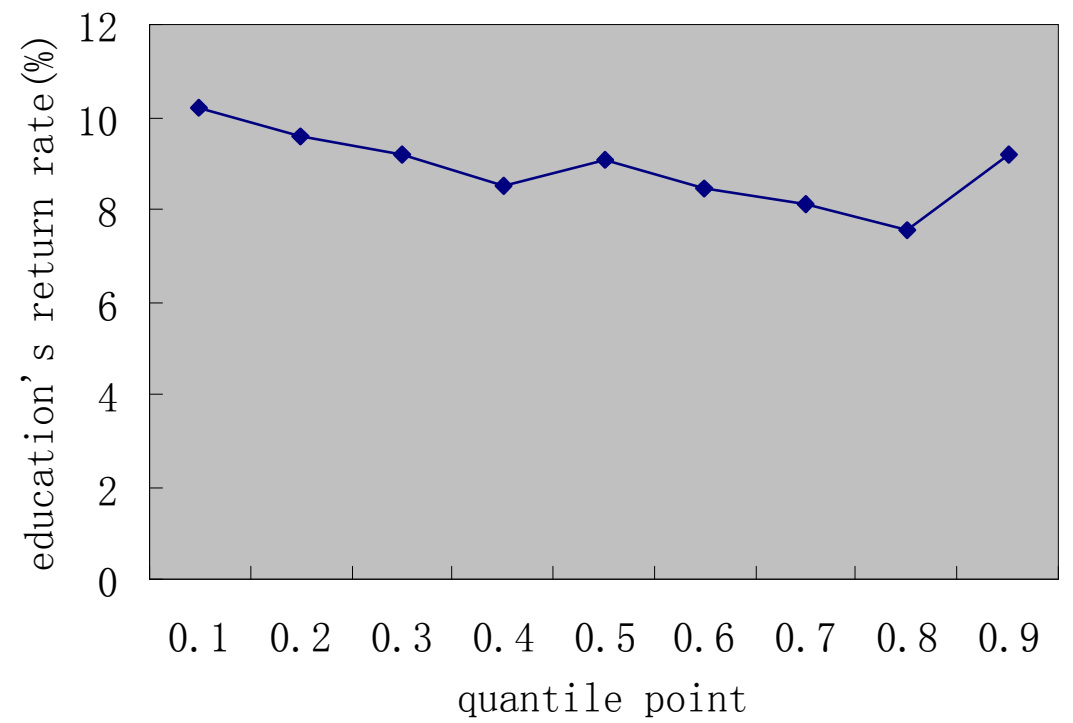

Fig. 1.The return rate to education at different quantile point (education year, 2005) 


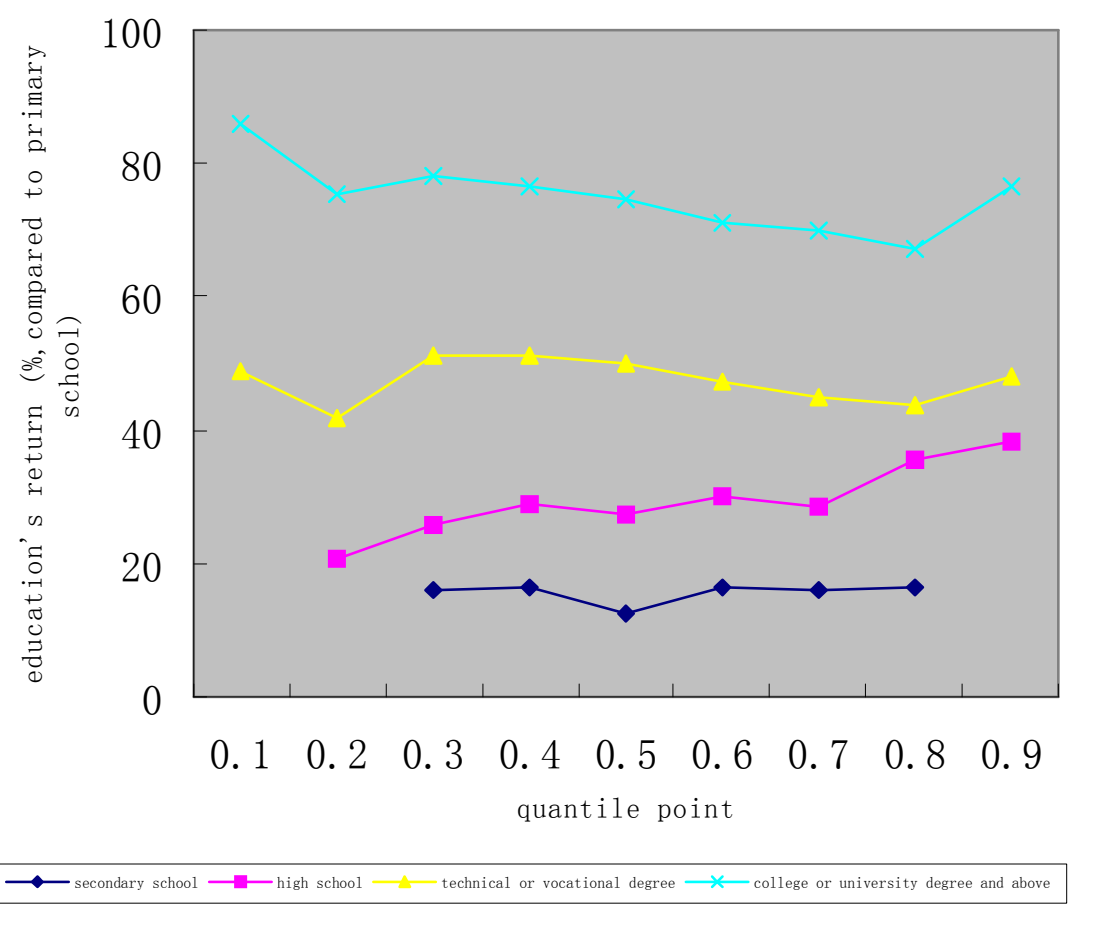

Fig.2. Education's return at different quantile point (education categories, 2005) 
Table1 Determinants of various types of income

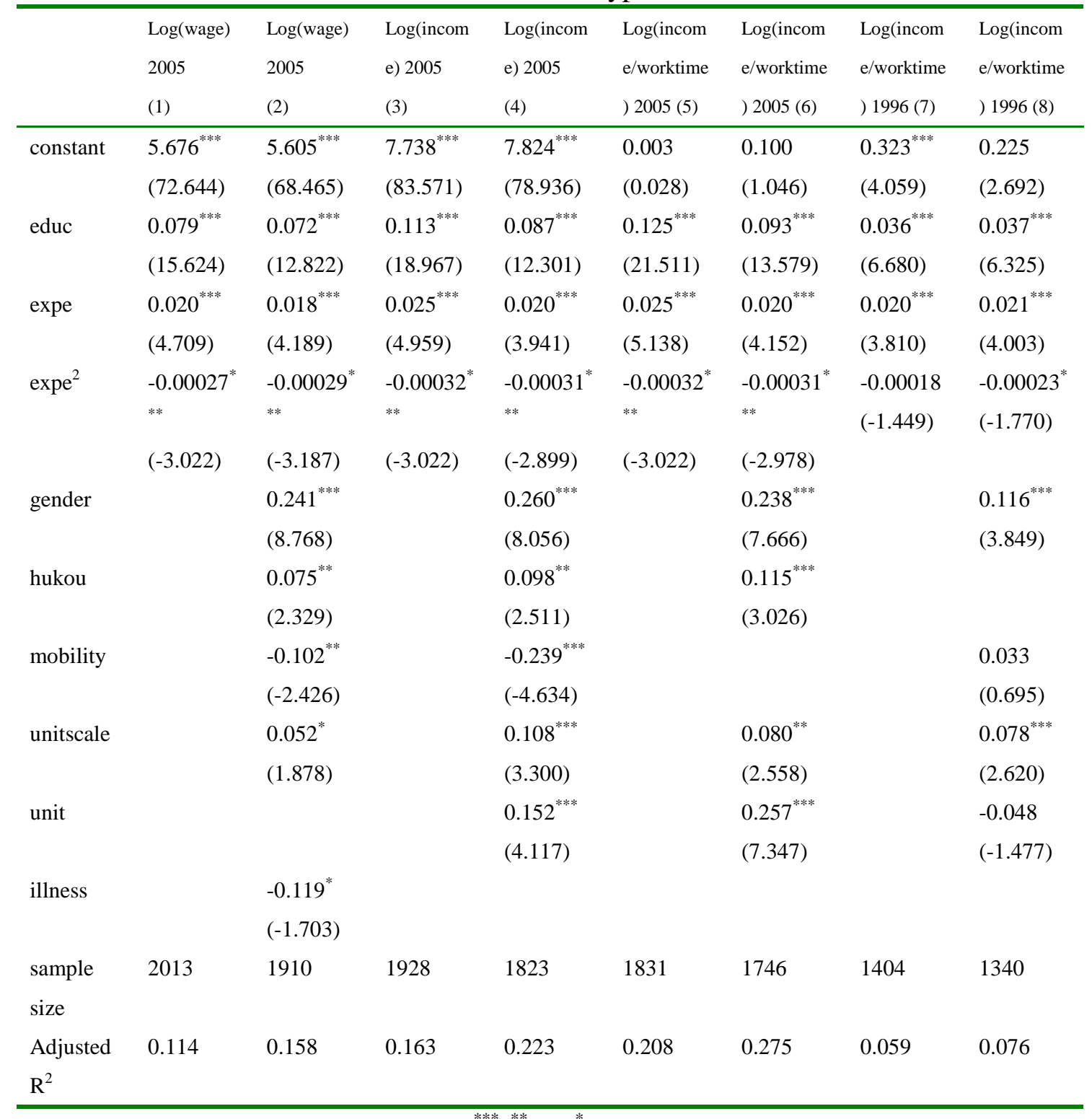

Note: $t$-statistic values are in parentheses. ${ }^{* * * * * *}$ and ${ }^{*}$ represent that the coefficient is significant at the $1 \%, 5 \%$, and $10 \%$ levels, respectively. 
Table 2 How does education affect income: the underlying mechanisms (2005)

\begin{tabular}{lllll}
\hline & $\begin{array}{l}\text { worktime (OLS) } \\
(1)\end{array}$ & $\begin{array}{l}\text { unit (logit, } \\
\text { state-owned } \\
\text { sector=1 })(2)\end{array}$ & $\begin{array}{l}\text { mobility (logit, } \\
\text { change job=1) } \\
(3)\end{array}$ & $\begin{array}{l}\text { illness (logit, } \\
\text { work loss due to } \\
\text { illness=1 ) (4) }\end{array}$ \\
\hline $\begin{array}{l}\text { constant } \\
\text { educ }\end{array}$ & $\begin{array}{l}2489.64^{* * * *}(37.33) \\
-22.35^{* * *}(-3.45)\end{array}$ & $1.360^{* * * *}[14.18]$ & $0.926^{* * * *}[-2.99]$ & $0.989[-0.24]$ \\
unit & $-230.66^{* * *}(-6.36)$ & & & \\
unitscale & $57.37^{*}(1.75)$ & & & \\
hukou & $-81.43^{* * *}(-2.08)$ & $4.997^{* * *}[11.88]$ & & 2000 \\
gender & & $1.413^{* * * *}[3.19]$ & & 0.0001 \\
Sample size & 1744 & 1984 & 2001 & \\
Adjusted R & 0.063 & 0.21 & 0.01 & \\
Pseudo R & & &
\end{tabular}

Note: The numbers in the parentheses are the $t$-statistic value, in brackets are $z$-statistic value. The coefficients in logit model are odds ratio coefficients. ${ }^{* * *},{ }^{* *}$ and ${ }^{*}$ represent that the coefficient is significant at the $1 \%, 5 \%$, and $10 \%$ levels, respectively. 
Table3 Education category, unit and occupational choice and income

\begin{tabular}{|c|c|c|c|c|c|}
\hline & $\begin{array}{l}\log (\text { income }) 2005 \\
\text { (1) }\end{array}$ & $\begin{array}{l}\text { Log(income) } 2005 \\
\text { (2) }\end{array}$ & $\begin{array}{l}\text { Log(income) } 2005 \\
\text { (3) }\end{array}$ & $\begin{array}{l}\text { Log(income) } 1996 \\
\text { (4) }\end{array}$ & $\begin{array}{l}\log (\text { income) } 1996 \\
\text { (5) }\end{array}$ \\
\hline constant & $3.882^{* * *}(12.989)$ & $4.871^{* * *}(16.199)$ & $4.336^{* * *}(14.323)$ & $5.063^{* * *}(12.265)$ & $5.113^{* * *}(12.421)$ \\
\hline secon & $0.163^{* * *}(2.959)$ & & $0.096^{*}(1.748)$ & $-0.032(-0.715)$ & $-0.055(-1.216)$ \\
\hline high & $0.316^{* * *}(5.116)$ & & $0.203^{* * *}(3.236)$ & $0.081^{*}(1.647)$ & $0.038(0.771)$ \\
\hline occup & $0.481^{* * *}(7.293)$ & & $0.287^{* * *}(4.189)$ & $0.023(0.381)$ & $0.022(0.370)$ \\
\hline univ & $0.769^{* * *}(11.413)$ & & $0.513^{* * *}(7.113)$ & $0.121^{* *}(1.997)$ & $0.124^{* *}(2.001)$ \\
\hline expe & $0.029^{* * *}(6.092)$ & $0.016^{* * *}(3.565)$ & $0.024^{* * *}(5.151)$ & $0.022^{* * * *}(3.797)$ & $0.022^{* * *}(3.704)$ \\
\hline $\operatorname{expe}^{2}$ & $-0.00050^{* * *}(-4.947)$ & $-0.00039^{* * * *}(-3.987)$ & $-0.00044^{* * *}(-4.419)$ & $-0.00032^{* *}(-2.283)$ & $-0.00030^{* *}(-2.173)$ \\
\hline gender & $0.270^{* * *}(9.068)$ & $0.232^{* * *}(7.491)$ & $0.219^{* * *}(7.225)$ & & $0.155^{* * *}(4.565)$ \\
\hline hukou & $0.102^{* * *}(2.767)$ & $0.184^{* * *}(5.072)$ & $0.112^{* * *}(3.026)$ & & \\
\hline mobility & $-0.130^{* * *}(-2.680)$ & $-0.139^{* * *}(-2.827)$ & $-0.130^{* * * *}(-2.692)$ & & \\
\hline unitscale & $0.118^{* * *}(3.757)$ & $0.148^{* * *}(4.610)$ & $0.132^{* * *}(4.190)$ & & $0.125^{* * *}(3.764)$ \\
\hline Log(workti & $0.601^{* * *}(15.917)$ & $0.587^{* * *}(15.362)$ & $0.596^{* * *}(15.924)$ & $0.424^{* * *}(7.789)$ & $0.402^{* * *}(7.403)$ \\
\hline me) & & & & & \\
\hline illness & $-0.087(-1.138)$ & $-0.061(-0.801)$ & $-0.071(-0.950)$ & & \\
\hline Unit & & & & & $-0.049(-1.370)$ \\
\hline Unit1 & $0.118^{* *}(2.055)$ & $0.142^{* *}(2.157)$ & $0.138^{* *}(2.131)$ & & \\
\hline Unit 2 & $-0.051(-0.779)$ & $0.075(1.052)$ & $0.084(1.206)$ & & \\
\hline Unit 3 & $-0.183^{* *}(-2.480)$ & $-0.141^{*}(-1.827)$ & $-0.075(-0.993)$ & & \\
\hline Unit4 & $-0.281^{* * *}(-3.179)$ & $-0.180^{*}(-1.929)$ & $-0.141(-1.537)$ & & \\
\hline Unit5 & $-0.495^{*}(-1.682)$ & $-0.916^{* *}(-2.515)$ & $-0.943^{* * *}(-2.644)$ & & \\
\hline Unit6 & $-0.132^{* *}(-2.188)$ & $0.008(0.113)$ & $0.057(0.841)$ & & \\
\hline Unit7 & $0.115(1.170)$ & $0.263^{* *}(2.469)$ & $0.276^{* * *}(2.641)$ & & \\
\hline Occup1 & & $-0.235^{* * *}(-3.854)$ & $-0.206^{* * *}(-3.438)$ & & \\
\hline Occup2 & & $-0.138^{* *}(-2.088)$ & $-0.090(-1.376)$ & & \\
\hline Occup3 & & $-0.263^{* * *}(-4.526)$ & $-0.189^{* * *}(-3.275)$ & & \\
\hline Occup4 & & $0.229(0.768)$ & $0.473(1.610)$ & & \\
\hline Occup5 & & $-0.489^{* * *}(-7.601)$ & $-0.299^{* * *}(-4.456)$ & & \\
\hline Occup6 & & $-0.739^{* * *}(-12.040)$ & $-0.524^{* * *}(-7.951)$ & & \\
\hline Occup7 & & $0.025(0.110)$ & $0.036(0.161)$ & & \\
\hline Occup8 & & $-0.401^{* *}(-2.152)$ & $-0.240(-1.307)$ & & \\
\hline Occup9 & & $-0.479^{* * *}(-5.628)$ & $-0.281^{* * *}(-3.219)$ & & \\
\hline Occup10 & & $-0.794^{* * *}(-12.390)$ & $-0.609^{* * * *}(-9.111)$ & & \\
\hline Occup11 & & $-0.560^{* * * *}(-2.718)$ & $-0.395^{*}(-1.951)$ & & \\
\hline
\end{tabular}




\begin{tabular}{lccccc}
\hline Sample size & 1682 & 1641 & 1641 & 1067 & 1031 \\
Adjusted $\mathrm{R}^{2}$ & 0.356 & 0.375 & 0.401 & 0.091 & 0.124 \\
\hline
\end{tabular}

Note: $t$-statistic values are in parentheses. ${ }^{* * * * * *}$ and ${ }^{*}$ represent that the coefficient is significant at the $1 \%, 5 \%$, and $10 \%$ levels, respectively. Unit 1 to Unit 7 are dummy variables, government department is used for comparison. Unit 1 is state service/institution; Unit 2 is state-owned enterprises; Unit 3 is small collective enterprise; Unit 4 is large collective enterprise; Unit 5 is family contract farming; Unit 6 is private, individual enterprise; Unit 7 is three-capital enterprise. The same is for occupations, senior professional/technical worker used for comparison. Occup 1 is junior professional/technical worker; Occup 2 is administration/executive/manager; Occup 3 is office staff; Occup 4 is farmer, fisherman and hunter; Occup 5 is skilled worker; Occup 6 is non-skilled worker; Occup 7 is army officer and police officer; Occup 8 is ordinary soldier and policeman; Occup 9 is driver; Occup 10 is service worker; Occup 11 is athlete, actor and musician. 
Table 4 Different factors' contribution to income $(\%, 2005)$

\begin{tabular}{lll}
\hline & Income (working months) (1) & Income (12 months) (2) \\
\hline educ & $10.9 \%$ & $9.6 \%$ \\
expe & $2.82 \%$ & $2.31 \%$ \\
gender & $1.56 \%$ & $1.49 \%$ \\
hukou & $0.77 \%$ & $0.46 \%$ \\
mobility & $-0.14 \%$ & $-0.064 \%$ \\
unit & $1.08 \%$ & $0.71 \%$ \\
unitscale & $0.35 \%$ & $0.34 \%$ \\
worktime & $49.4 \%$ & $14.45 \%$ \\
constant & $33.26 \%$ & $70.70 \%$ \\
unobservable factors & $6.4 \%$ & $6.1 \%$ \\
Sample size & 1738 & 1738 \\
Adjusted $\mathrm{R}^{2}$ & 0.324 & 0.218 \\
\hline
\end{tabular}


Table 5 Mean value and coefficient of the variable (full sample and low-income group, 2005)

\begin{tabular}{lllll}
\hline & Full sample & & Low-income & group \\
\hline Mean & $\begin{array}{c}\text { Coefficient } \\
\text { (significant) }\end{array}$ & Mean & $\begin{array}{l}\text { Coefficient } \\
\text { (significant) }\end{array}$ \\
\hline educ & 11.21 & 0.091 & 9.75 & 0.029 \\
expe & 22.02 & 0.021 & 22.67 & \\
expe $^{2}$ & 601.83 & -0.00033 & 658.25 & \\
gender & 0.61 & 0.24 & 0.48 & 0.099 \\
hukou & 0.72 & 0.1 & 0.58 & \\
mobility & 0.1 & -0.13 & 0.17 & \\
unit & 0.48 & 0.21 & 0.23 & 0.125 \\
unitscale & 0.36 & 0.09 & 0.30 & 0.487 \\
worktime & 7.58 & 0.61 & 7.47 & 4.50 \\
constant & & 3.09 & & \\
Unobservable & 0.59 & & 0.40 & 521 \\
factors & & & 8.56 & 0.336 \\
Log(income) & 9.36 & 1726 & & \\
Sample size & & 0.332 & & \\
Adjusted ${ }^{2}$ & & & &
\end{tabular}

